\title{
Making Some Sense of the Paradox: Polyphony, Conflicting Ideologies, Dialogism, and the Dialectic Dynamics of Ecclesiastes
}

\author{
BARbara M. Leung Lai (TyNdale University, Toronto, CANAdA)
}

\begin{abstract}
Rooted in the rubrics of "Text and Reading," this article correlates some of the new advances in the study of Ecclesiastes in the recent past. ${ }^{2}$ Employing four intentionally hammered out reading strategies-reading polyphonically; reading "cross the grains"; reading dialectically and reading narrativally, it seeks to demonstrate that the integration of four perspectival readings will enrich the meaning-significance of the book. Moreover, it aims at a proposal that would make some sense of this paradoxical book.
\end{abstract}

* Submitted: 24/04/2021; peer-reviewed: 29/10/2021; accepted: 26/11/2021. Barbara M. Leung Lai, "Making Some Sense of the Paradox: Polyphony, Conflicting Ideologies, Dialogism, and the Dialectic Dynamics of Ecclesiastes," Old Testament Essays 34 no. 3 (2021): 902 - 914. DOI: https://doi.org/10.17159/23123621/2021/v34n3a14.

1 I have adopted the ethos behind one's chosen reading strategy, which is that "the question you ask determines the answer you get." The four "ports of entry" proposed in this paper represent the four macro-questions I ask of the text of Ecclesiastes as an interested and engaged reader.

2 See the collection of essays in The Words of the Wise Are Like Goads: Engaging Qohelet in the 21 st Century (ed. Mark J. Boda, Tremper Longman and Cristian G. Rata; Winona Lake: Eisenbrauns, 2013); Barbara M. Leung Lai, "Voice and Ideology in Ecclesiastes: Reading 'Cross the Grains,'" in Interested Readers: Essays on the Hebrew Bible in Honor of David J. A. Clines (ed. James K. Aitken, Jeremy M. C. Clines and Christl M. Maier; Atlanta: SBL, 2013), 265-278; eadem, "The Preacher and One's Own 'Text-of-life'," in Global Perspectives on the Old Testament (ed. Mark Roncace and Joseph Weaver; Upper Saddle River: Pearson, 2013), 214-216; eadem, "Toward a Version of 'Narratival Hermeneutics'-Reading Ecclesiastes Ethno-culturally with a Chinese Lens: Selfhood, Diaspora Experience, and the Search for Meaning," in Reading In-between: How Minoritized Cultural Communities Interpret the Bible in Canada (ed. Néstor Medina, Alison Hari-Singh and Hyeran Kim-Cragg; Eugene: Pickwick Publications, 2019), 36-51; eadem, "Engaging Ecclesiastes Narrativally and Polyphonically with a Chinese Lens: Traditional Wisdom and "Collective Lived Experience under the Sun' in Dialogue," in $T$ \& T Clark Handbook of Asian American Biblical Hermeneutics (ed. Uriah Y. Kim and Seung Ai Yang; London: T \& T Clark, 2019), 306-316. 
KEYWORDS: Polyphony, Dialogism, "Dialogic Truth," Dialectic, Narratival Hermeneutics, Reading "Cross the Grains" (CrossGraining)

\section{A INTRODUCTORY REMARKS}

To the interested, engaged reader, four inner-textual observations contributed to the ambiguity of this strange book-Ecclesiastes. First, we have the surfaced conflicting ideologies (cf. Deut 11:26-28; 28 versus Eccl 6:1-6; 7:15; 8: 14-15). In the captivating "I"-voice of the Qoheleth, there are apparently a multiplicity of speaking voices that create both the dialogic and dialectic dynamics within the twelve chapters. Second, the deeply reflective and yet "thinking-out-loud" mode of expression of Qoheleth gives the impression of the lack of any logical and structural development in the book. Third, while the pessimistic summary appraisal—"Utterly senseless! Everything is meaningless" $(1: 2,14 ; 2: 1 ; 4: 16$; 12:8 etcetera) pronounced by Qoheleth's enticing "I" voice is dominant, seven uplifting and kerygmatic "carpe diem" short sayings appear sparingly throughout the twelve chapters $(2: 24 ; 3: 12-13 ; 3: 22 ; 5: 18-19 ; 8: 15 ; 9: 7-10 ; 11: 9-10)$. Fourth, the epilogist's closing remarks in 12:9-14 breaks the dialogic and dialectic thrust of one's reading, leaving the notion of an abrupt and dogmatic concluding statement - most unsatisfying and to a certain extent, troubling to the reader. $^{3}$

\section{B READING ECCLESIASTES}

Reading Ecclesiastes demands an integrated, multi-perspectival strategy tailored to possess a certain degree of intentionality. The observations stated above have generated scholarly engagements in the recent past and fruits of such endeavours provide pointers and directives to newer ways of approaching the book. As a heuristic attempt, I have identified four ports of entry for reading. It is hoped that these four distinct readings together will provide some relevant tools for understanding this paradoxical book.

3 Note that the lamenting summary appraisal of Qoheleth in 12:8, ("Utterly meaningless! Everything is meaningless!"), immediately precedes the epilogist's concluding remarks (12:9-14). 


\section{$1 \quad$ Reading Ecclesiastes as a Polyphony}

1a Voice and Ideology

The interface of voice and ideology is firmly established in the field of biblical studies. ${ }^{4}$ Ecclesiastes is predominantly an "I"-text ${ }^{5}$ but it is also multi-voiced. Identification of the different voices represented in Ecclesiastes has been an area of interest especially in the recent past. ${ }^{6}$ Incorporating earlier attempts, Kyle R. Greenwood has provided a precise analysis of the three voices in the book. ${ }^{7}$

First is the collective voice of the sages, regarded as the "true voice of wisdom," which primarily speaks in the second-person imperative (e.g., 1:3-11; $3: 1-8 ; 4: 5-6 ; 9-13)$. It represents the wisdom tradition in ancient Israel (or the embedded ideology of the text, i.e., Qoheleth's pretext). The second voice is the voice of Qoheleth speaking as Solomon in the captivating first-person "I"-voice (e.g., $1: 12-15 ; 17-18 ; 2: 3-14 ; 4: 1-4)$. It signifies the reshaped ideology of Qoheleth which is cast in sharp contrast with the ideology ingrained in the text (i.e., the wisdom tradition). The third voice serves as that of the "frame narrator" and is found in the third person sections of chapters 1 and 12 (cf. 1:1-2a, 7:27a; 12: 8a). My reading leads me to add to these identifiable voices two other voices: (1) the voice of the epilogist in 12: 9-14 who seeks to provide a quick fix to the surfaced tensions from chapter 1 to 12:8 through Qoheleth's search for meaning; ${ }^{8}$

4 See Leung Lai, Through the "I" Window: The Inner Life of Characters in the Hebrew Bible (HBM 34; Sheffield: Sheffield Phoenix Press, 2011), 37-39; Kyle R. Greenwood, "Debating Wisdom: The Role of Voice in Ecclesiastes," CBQ 74 (2012): 476-491; Frances Landy, "Vision and Voice in Isaiah," JSOT 88 (2000): 19-36; eadem, "The Impersonal Voice in the First-person Narrative Fiction," Narrative 12 (2004): $113-151$.

5 An I-text is one in which the character speaks in the first-person "I"-voice. Examples of "I"-texts in the Hebrew Bible are the majority of the Psalms in the book of Psalms; Nehemiah; Dan 7-12, etcetera.

6 See Robert D. Holmstedt, "אני ולבי: The Syntactic Encoding of the Collaborative Nature of Qohelet's Experiment," Journal of Hebrew Scriptures 9 (2010): 476-491; Craig G. Bartholomew, Ecclesiastes (Baker Commentary of the Old Testament: Wisdom and Psalms; Grand Rapids: Baker Academic, 2009), 75-83, has summarised and responded to Michael Fox's analysis of the speaking voices in Ecclesiastes. See Michael Fox, "Frame-Narrative and Composition in the Book of Qohelet," HUCA 48 (1997): 83-106.

7 Kyle R. Greenwood, "Debating Wisdom: The Role of Voice in Ecclesiastes," $C B Q$ 74 (2012): 476-491.

8 Based on three grounds, I see the voice of the epilogist in 12:9-14 as a distinct voice from that of the "frame narrator." First, the narrator introduces Qoheleth's last reflection on life in 12:8a ("Utterly senseless! Everything is meaningless!"), immediately before the concluding statements in 12:9-14. This breaks the dialogic and dialectic thrust of the text. Second, the narrator plays a very passive role within the twelve chapters $(1: 1-2 \mathrm{a} ; 7: 27 \mathrm{a} ; 12: 8 \mathrm{a})$, providing a framing for the "narrative reading" 
and (2) the inner voice of Qoheleth which emerges from imaginary dialogues within monologues (e.g., "I said in my heart saying, I, behold"9; cf. 1:16; 2:1-2; $2: 15 ; 3: 17)$.

Along this stated interpretive path, there is another voice, the interpretive voice of the reader representing the readerly ideology one brings to the text, interacting with the embedded textual ideologies (of traditional wisdom and the reshaped ideology of the Qoheleth). Therefore, there are potentially six voices/sets of ideology engaging in vibrant interactions with one another, both dialogically and dialectically (i.e., creating conflicting opinions through vivacious dialogues).

Considering polyphony as the characteristic feature of Ecclesiastes, the analysis and textual dynamics of narration, reflection, inner debate, elucidation and resolution (especially the role of the epilogist in 12:9-14) take on new dimensions of meaning. Moreover, the intertwining of speaking voices in Ecclesiastes provides a framing for reading and hearing the text. ${ }^{10}$

1b The Bakhtinian Theories of Polyphony and Dialogism

Multi-voices engaging in vibrant dialogues within the chapters characterise the nature of the textual dynamics of Ecclesiastes. Mikhael Bakhtin's notion of polyphony and dialogism proceed from his analysis of the work of the Russian novelist, Fyodor Dostoevsky. According to Bakhtin, Dostoevsky's writings possessed and approximated a genuine dialogue between author, characters and consciousness. This concept may potentially provide an additional dimension to

of the book. It is not in accord with the diction of the dogmatic declarations made by the epilogist. Third, readers will find the sudden transition from 12:8 to 12:9-14 too disconcerting. This leads to the idea that someone (an epilogist) other than the frame narrator is trying to provide a quick fix to the recurring "utterly senseless" cry of Qoheleth.

9 It is a triple emphatic use of Qoheleth's "I"-voice here. As Adele Berlin has noted, " הנה functions almost like an interior monologue," an "internalized viewpoint" that provides a kind of "interior vision"; Adele Berlin, Poetics and Interpretation of Biblical Narrative (Winona Lake: Eisenbrauns, 1994), 62-63. Elsewhere in the narrative portions of the Old Testament (e.g., Gen 17:17; 18:12), the "interior monologue" is often perceived as the narratorial intent to bring something out to the foreground. However, "inner-voice" in Ecclesiastes functions to create a space for the "resolution of existing tensions and inner debates." It is more significant in that Ecclesiastes is both an "I"-text (where the main character speaks in the first person "I"-voice" all the time) and a "polyphony" with several dialogic and dialectic layers of vibrant interaction. Qoheleth himself introduces his own "inner voice" in an emphatic way. It is not the intent of the frame narrator who apparently plays a more passive role in the book.

10 For texts of a polyphonic nature, the practice of "hearing the text" (i.e., "the hermeneutics of hearing") is perhaps, a necessity. See Klyne Snodgrass, "Reading to Hear: A Hermeneutics of Hearing," HBT 24 (2002): 1-32. 
the significance of the presence of multiple speaking voices (interior or exterior, individual or corporate). ${ }^{11}$ Further, this polyphonic characteristic may have profound implications for the so-called Bakhtinian "dialogic truth" to be appropriated in the reading of Ecclesiastes. More explicitly, "dialogic truth" points to the meaning of a text through the polyphonic-dialogic mode of expression/presentation.

Essential to the Bakhtinian concepts of discourse or literature is that the basic unit of speech is not the sentence construct or even the word but the "utterance." Any utterance or discourse, whether spoken or written, is always addressed to someone and therefore possesses a dialogic quality. ${ }^{12}$ The foundation of Bakhtin's ideology is the view that any form of discourse is always a reply and therefore always takes shape in response to what has already been said. This also includes "the background of other concrete utterance on the same theme, a background made up of contradictory opinions, points of view and value judgments." 13 Carol A. Newsom adds that:

An utterance is also shaped by an orientation to the listener in anticipation of what might be said by one who ears it. Thus, no matter how monologic the form of utterance, one can inquire about the way in which it is implicitly dialogized by its orientation to the already said and the yet to be said. ${ }^{14}$

The implications of appropriating Bakhtinian perspectives on polyphony and dialogism to the speaking voices in Ecclesiastes are significant. To elaborate further, the Bakhtinian perception of "dialogic truth" introduces a whole new dimension of the function of Qoheleth's "monologic/dialogic" discourse including the "saying in his own heart," (e.g., 1:16; 2:1, 15). As pioneers of speaking voice analysis, Meir Sternberg and L. Alonso Schökel have succeeded in exemplifying "monologue-dialogue" in the Hebrew Bible. ${ }^{15}$ Contained in the pericope are pockets of monologue within dialogue and imaginary dialogues

11 See Mikhael M. Bakhtin, The Dialogic Imagination: Four Essays (ed. Michael Holquist; trans. Caryl Emerson and Michael Holquist; Austin: University of Texas Press, 1986); idem, "The Problem of Speech Genre," in Speech Genre and Other Late Essays (trans. V. McGee; Austin: University of Texas Press, 1986); idem, Problems of Dostoevsky's Poetics (ed. and trans. Caryl Emerson; Minneapolis: University of Minnesota Press, 1984); Carol A. Newsom, "Bakhtin, the Bible, and Dialogic Truth," JR 76 (1996): 290-306 (295); eadem, "The Book of Job as Polyphony Text," JSOT 97 (2002): 87-108.

12 See Bakhtin, "The Problem of Speech Genre," 60-102.

13 Ibid., Dialogic Imagination, 281.

14 See Newsom, "The Book of Job as Polyphonic Text," 90.

15 Meir Sternberg, "The World from the Addressee's Viewpoint: Reception as Representation, Dialogue as Monologue," Style 20 (1986): 295-318. See also L. Alonso Schökel, A Manual of Hebrew Poetics (Rome: Editrice Pontificio Istituto Biblico, 1998), 178. 
within monologues. In fact, one can collapse the distinction between monologue and dialogue as they serve the same function of self-representation. Alonso Schökel further qualifies monologue as "the breaking into a context of dialogue with a reflection directed to oneself." 16 Ecclesiastes is a polyphony, and it is also an "I"-text where Qoheleth speaks in the first-person "I"-voice all the time. This dialogic-interacting dynamic fits in beautifully with Qoheleth's "monologicdialogic" mode of expression. Qoheleth is entering freely into vibrant dialogue with the other speaking voices - that of the frame narrator in 1:1-2a and 7:27a, the collective voice of the sages (the traditional wisdom), his own "inner voice" and the voice of the epilogist in 12:9-14. It is through this "dialogic" textual dynamic of the merged, that is, Qoheleth's inner voice (e.g., 1:16; 2:1-2; 2:15]) and unmerged speaking voices that the so-called Bakhtinian "dialogic truth" is distinctively brought to the foreground and the moral of the text is to be attained.

\section{Reading Ecclesiastes through "Cross-graining"}

2a Reading "with the Grain" and "against the Grain"

Using the imagery of woodwork, all texts are said to have grains or directionality, just like wood. I have picked up Newsom's "plywood" analysis here but with a more focused appropriation. ${ }^{17}$ Along the ideological-critical path of any given text, there are two conventional reading strategies namely reading "with the grain" and "reading against the grain."

The textual dynamics within the twelve chapters indicate that there are at least three levels of ideological critique at work in Ecclesiastes. First, Qoheleth is interacting "against the grain" of the ideologies embedded in traditional Israelite wisdom (his "pretext"). Second, Qoheleth is inviting all readers (his first readers and contemporary readers), from their/our different ideological locations, to respond to his discourse "with the grain" through his compelling "I"-voice. ${ }^{18}$ Third, as an interpretive choice, the reader is potentially responding "against the grain" to the epilogist's over-simplistic way of providing a quick fix to defend the ideology of traditional wisdom or "with the grain" to the epilogist's attempt to "making-it-right" in the concluding remarks (12:9-14). In this case, both "reading with" or "against the grain" are possible alternatives.

16 Schökel, A Manual of Hebrew Poetics, 81.

17 See Newsom, "Reflection on Ideological Criticism and Postcritical Perspectives," in Method Matters: Essays on the Interpretation of the Hebrew Bible in Honor of David Patterson (ed. Joel M. LeMon and Kent Harold Richards; Atlanta: SBL, 2009), 553557.

18 This could be considered a unique example in the Hebrew Bible. 


\section{2b Reading "Cross the Grains"}

For ideological-critical endeavours, reading "against the grain" seems to be the norm. Engaging Ecclesiastes calls for a reading that is "crossing the grains." "Cross-graining" is applied to the production of plywood by gluing together layers (veneers) of adjacent piles having the wood grain at right angle to each other to form a high quality, good-strength wood panel. Specifically, plywood is bonded with grain running against one another and perpendicular to the grain direction. Thus, several thin layers of wood bonded together would be stronger than one single thick layer of wood. It produces the strongest kind of wood that is hard to bend. I have found this "cross-graining" imagery quite fitting to a reading strategy that incorporates both conventional "against the grain" and "with the grain" and has the potential of moving towards a multi-layered, more enriched meaning of the text.

There are subsequently four potential ideologies represented in "crossgraining" by engaged readers: (1) the ideology of traditional wisdom to which Qoheleth is interacting "against the grain" (7:15; 8:14); (2) the multi-layered ideology upheld by Qoheleth and rooted in his community's collective lived experience $(4: 1-3,4-6,7-12)$; (3) the reshaped ideology proposed by the narrator and especially by the epilogist in 12:9-14 which counteracts the ideology presented by Qoheleth; and (4) the readerly ideology as a result of "cross graining" - navigating through the options of one's interpretive choice and negotiating by placing the existing interpretive tensions side-by-side as an enriched whole.

The woodwork imagery of the production of plywood fits beautifully into this endeavour. I aim at uncovering the existence of the many cross-graining fibres that constitute Ecclesiastes, that is, the collective message of the book.

\section{Reading Ecclesiastes Dialectically}

Ecclesiastes is a book engrained with dialectic tensions that are of polar nature (e.g., "the house of mourning" and "house of feasting"; "the heart of the wise" and "the heart of the fool" in 7:1-5; "the righteous perishing" and the "the wicked living long" in 7:15). Three observations can be obtained in unpacking this statement.

\section{3a Observation (1)}

First, Qoheleth holds on to the ideology that all attempts to search for the "order of things" in this chaotic world will meet with sheer disappointment $(7: 15-28 ; 8$ : $12,14 ; 12: 8)$. As a resistant explorer/seeker of realities laid out in classical wisdom, Qoheleth's loud remark in 10:5 touches the core and true dynamic of his search for the "order of things"- "There is an evil [רעה] I have seen under the sun, like an error [כשגגה] that comes from a ruler." The ideology ingrained in the text - "Fear God and keep his commandments" is required for all humanity 
(12:13). Qoheleth seeks to embrace both in all flesh but finds it burdensome and oppressive (cf. especially 10:5; 8:16). The epilogist seeks to defend the latter by underscoring, twice in the "afterword," the expression, "And more than that [ויתר שהמה] [ויתר] ..." (12:9) and "more than these (12:12). Two sets of ideology are presented side by side. My attempt is neither to seek to harmonise (or synthesise) the two conflicting ideologies nor to pick one against the other as a hermeneutical choice. A "cross-graining" reading strategy helps to put the two conflicting ideologies side by side as a "co-existing reality."

\section{3 b Observation (2)}

Second, dialectic inner tensions exist in Qoheleth's formulation and development of his ideology rooted in the commonality of humanity's collective lived experience under the sun. On the one hand, Qoheleth affirms the sovereignty and justice of God over the absurdity and nonsensicality of human life (cf. 2:26; $3: 10-11,14-15 ; 4: 18 ; 7: 18,29 ; 8: 12-13 ; 9: 1$ in their immediate contexts) and on the other hand, he is overwhelmed by the collapse of the "order of things" in the realities of human existence and embraces these co-existing dialectic tensions in all flesh.

\section{3c Observation (3)}

Third, the presence of the seven uplifting, kerygmatic "carpe diem" sayings $(2: 24 ; 3: 12-13 ; 3: 22 ; 5: 18-19 ; 8: 15 ; 9: 7-10 ; 11: 9-10)$ amidst Qoheleth's pessimistic "I"-discourse which run through the twelve chapters until 12:8 creates another dialectic tension. The magnitude of absurdity in life $(2: 7 ; 3: 16-$ $17 ; 7: 15 ; 8: 12-14)$ drives Qoheleth to a weighty summary appraisal-seeking to make some sense out of the nonsensicality in life is like "a chasing after the wind" -doomed to fail! These seven sayings encourage readers to seize the day and live life fully before God with all its enjoyments, for they are good gifts from Godour lot/portion. The seven sayings appear sparingly within the twelve chapters. Somehow, they break the vein as one reads either "with the grain" or "against the grain." They are at odds with the dialogic dynamic of the book and their appearance thus causes some concerns as to the structure of the whole book. John Kessler sees the seven as "theological compromise" in such a pessimistic book. ${ }^{19}$ Mark Boda takes their function as affirming the bodiliness of creaturely life and making the best out of the situation is the key. ${ }^{20}$ Even in the context of the dialectic momentum within the textual dynamics, the sayings are uplifting, encouraging, appealing and rooted in the flesh and blood lived experience of the community of Israel. Their appearance affirms the other side of the reality-

19 John Kessler, Old Testament Theology: Divine Call and Human Response (Waco: Baylor University Press, 2013), 275.

20 See Mark Boda, "Speaking into the Silence: The Epilogue of Ecclesiastes," in The Word of the Wise (ed. Mark J. Boda, Tremper Longman and Cristian G. Rata; Winona Lake: Eisenbrauns, 2013), 257-282. 
amidst the nonsensicality of life, there is still the call for "live life along with all its enjoyments, for they are God's good gifts." Qoheleth embraces both realities (absurdity and enjoyment of life) in all flesh. In 2:17-18 where Qoheleth declares that he hates life ("Therefore, I hated life... Yes, I hated all my labor that I labor under the sun"), this declaration adds on another layer of his tension in the light of the overarching dialectic feature of Ecclesiastes.

\section{$4 \quad$ Reading Ecclesiastes "Narrativally"}

To coin the term "Narratival Hermeneutics, " Canadian contributors of the 2019 collection, Reading In-between: How Minoritized Cultural Communities Interpret the Bible in Canada ${ }^{21}$ came up with demonstrated examples of "narratival hermeneutics" through their collaborative effort. As a working agenda, "narratival hermeneutics" is a reading (or interpretive path) that takes seriously the flesh and blood collective lived experience of the first readers as well as the community of contemporary readers as the contexts for interpretation. ${ }^{22}$ The commonality of this "cross-culture and time" reading is found in the "under the sun" human experience. Ecclesiastes is utterly anthropocentric, the observations, narrations, inner debates and summary appraisals are all rooted in the flesh and blood collective human experience "under the sun." Appropriating such reading strategy to Ecclesiastes is proven to be fruitful. The case in point is that the vibrant dynamics and power in the art and science of "narratival hermeneutics" could be brought to the foreground through such endeavour. ${ }^{23}$

$4 \mathrm{a}$ Cycle of Observation: A Step-by-step Formulation of one's "Text-ofLife/Life-Text"

The "I"-discourse portion in the book provides us a step-by-step guidebook in formulating the significant episodes of Qoheleth's "text-of-life/life-text." These steps are not merely life's important milestones but layers of cumulative wisdom. The cycle of "turning-seeing-reflecting-perceiving-concluding" (1:14-18; 2:111, 12-26; 3:16-22; 4:1-3, 4-6, 7-10, 11-12, 15-16; 5:12-19 [Eng. 13-20]; $6: 1-12 ; 7: 15-18,25-29 ; 8: 10-12,14-17 ; 9: 1-10,11-12,13-18 ; 10: 5-15)$ characterises Qoheleth's persistent and intentional engagement in life. From the intentional "turning" (שוב, e.g., 4:1, 7) to the deep level of engagement (e.g., 8:16 "When I gave my heart to know wisdom, and to see the task that is done on the earth, for even by day and by night, he does not see sleep in his eyes")

21 Néstor Medina, HyeRan Kim-Cragg and Alison Hari-Singh, eds., Reading Inbetween: How Minoritized Cultural Communities Interpret the Bible in Canada (Eugene: Pickwick Publications, 2019).

22 It is a commonly accepted maxim that "all content is subject to context" and "there is no text without context." See Anita Fetzer and Etsuko Oishi, eds., Context and Contexts (Amsterdam: John Benjamin Publishing, 2011), 171.

23 See Leung Lai, "Toward a Version of 'Narratival Hermeneutics."” 
signifies a dynamic process of self-engagement. The components in this cycle of life-exploration are not derived from a mechanical step-by-step manual but one that best exemplifies the vibrant dynamics of a seeker, an explorer of life - the Qoheleth.

\section{4b Common Denominator}

With the shared common denominator of the "collective lived-experience under the sun," readers can echo each of the outpoured cries of Qoheleth and the deeprooted, burdensome (though occasionally uplifting) concluding statements he utters. The ideological reflections of Qoheleth are not constructed sophistically or after a rigid frame of reference. Rather, they are rooted in the "flesh-and-blood" collective lived experience of all humanity. This demonstrates the power of "narratival hermeneutics." While the common denominator of all life's observations is rooted in the "human experience under the sun," the power and dynamics of these observations, narrations, reflections and conclusions help to underscore the what's in life's realities and the how's in embracing the coexisting dialectic tensions. To a certain extent, this paper is yet another version of "narratival hermeneutics." It provides a mapping of the practice of narratival hermeneutics, laying out a robust drama of the dogma rooted in humanity's collective lived experience under the sun.

\section{CONCLUSION: MAKING SOME SENSE OF THE PARADOX}

Ecclesiastes is indeed an ambiguous and complex book. In keeping with its characteristic nature, I have intentionally employed four distinct reading strategies in the above discussion: (1) reading polyphonically (i.e., as a multivoiced book); (2) reading ideological-critically (i.e., as a text with clashing ideologies represented by the speaking voices [spoken or submerged]); (3) reading dialectically (i.e., as a book creating layers of dialectic tension that are of polar structure) and (4) reading "narrativally" (i.e., as an appropriated case for "narratival hermeneutics"). To some extent, these perspectival readings together have yielded a multi-layered, enriched outcome for the meaning-significance of the book.

Ecclesiastes is wisdom literature. Roland Murphy's maxim underscores the need for some reshaping of our impression of the ambiguous nature of this strange book. He stated that "every gnomic saying needs a balancing corrective." ${ }^{24}$ Leo G. Perdue is perceptive in proposing that "the dialectic of cosmology/theodicy and anthropology" is the best approach to the study of

24 Identified as his "axiom”; see "Murphy's Axiom: Every Gnomic Saying Needs a Balancing Corrective," in Urgent Advice and Probing Questions (ed. James L. Crenshaw; Macon: Mercer University Press, 1995), 344-354. 
wisdom literature (in our case, Ecclesiastes). ${ }^{25}$ The two contrasting concepts should be held in true dialectic with each other. ${ }^{26}$ In the context of the commonality, that is, humanity's experience under the sun, all interested parties (speaking voices in Ecclesiastes and contemporary readers) can witness the coexistence of the two sets of reality, at least two layers of conflicting ideology. Upholding both ideologies and being sustained in this dialectic tension is, perhaps, the moral of Ecclesiastes.

In majority of cases, the question you ask will determine the answer you get. I set out to ask one question of the text: "How do we make some sense of this paradoxical book"? Perhaps, I need to re-address the question with more focus. We assume what we are dealing with here is a "paradox" and seek to find some resolutions to tone down the ambiguity of this strange book. Timothy Walton's insightful comment may provide new perspectives for our case in point. He states that as one of the three readerly choices, readers "can allow the truth of both perspectives to remain side by side and confess that a solution to how these can both be true escapes us, even the wisest among us (cf. 8:17)."27 "Reading cross the grains" enables us to make such an informed choice.

If Ecclesiastes underlines a paradigm of "How to Live" and it is rooted in the commonality of the "collective lived experience of all humanity under the sun," it calls for a re-orientation for all engaged readers. If the nature of the book is paradoxical, then, let it remain a "paradox." In the context of "lived experience under the sun," conflicting ideologies, layers of dialectic tension, laments for the nonsensicality and absurdity of life alongside of encouragements to enjoy life with all its pleasures - these features are all within the normality of the realities

25 Leo G. Perdue, Wisdom and Creation: The Theology of Wisdom Literature (Nashville: Abingdon, 1994), 48.

26 Ibid.

27 Timothy Walton, "Reading Qoheleth as Text, Author, and Readers," in Tradition and Innovation in Biblical Interpretation: Studies Presented to Professor Eep Talstra on the Occasion of His Sixty-fifth Birthday (ed. W. Th. Van Peursen and J. W. Dyk; Leiden: Brill, 2011), 130. 
of human life. The reshaped perspective on life is that "embracing co-existing dialectic tensions that are of polar nature" is the way "to live." This is the moral of this paradoxical book. It takes a text with such complex features to serve this goal and to bring this message to the foreground in the broader context of the "Grand Narrative." Amidst the harshness of life, there are still glimpses of uplifting momentum (cf. 7:29; 8:12b; 11:7-9; 12:9-12).

\section{BIBLIOGRAPHY}

Alonso Schökel, L. A Manual of Hebrew Poetics. Rome: Editrice Pontificio Istituto Biblico, 1998.

Bakhtin, Mikhael M. The Dialogic Imagination: Four Essays. Edited by Michael Holquist. Translated by C. Emerson and M. Holquist. Austin: University of Texas Press, 1986.

"The Problem of Speech Genre." Pages 60-102 in Speech Genre and Other Late Essays. Translated by V.W. McGee. Austin: University of Texas Press, 1986.

.Problems of Dostoevsky's Poetics. Edited and Translated by C. Emerson. Minneapolis: University of Minnesota Press, 1984.

Bartholomew, Craig G. "Ecclesiastes." Pages 75-83 in Baker Commentary of the Old Testament: Wisdom and Psalms. Grand Rapids: Baker Academic, 2009.

Berlin, Adele. Poetics and Interpretation of Biblical Narrative. Winona Lake: Eisenbrauns, 1994.

Boda, Mark J., Tremper Longman and Cristian G. Rata, eds. Words of the Wise Are Like Goads: Engaging Qohelet in the 21 st Century. Winona Lake: Eisenbrauns, 2013.

"Speaking into the Silence: The Epilogue of Ecclesiastes." Pages 257-282 in The Word of the Wise Are Like Goads: Engaging Qohelet in the 21st Century. Edited by Mark J. Boda, Tremper Longman and Cristian G. Rata. Winona Lake: Eisenbrauns, 2013.

Fetzer, Anita and Etsuko Oishi, eds. Context and Contexts. Amsterdam: John Benjamins Publishing, 2011.

Fox, Michael. "Frame-Narrative and Composition in the Book of Qohelet." Hebrew Union College Annual 48 (1997): 83-106.

Greenwood, Kyle R. "Debating Wisdom: The Role of Voice in Ecclesiastes." Catholic Biblical Quarterly 74 (2012): 476-491.

Holmstedt, Robert D. "אני ולבי: The Syntactic Encoding of the Collaborative Nature of Qohelet's Experiment." Journal of Hebrew Scriptures 9 (2010): 476-491.

Kessler, John. Old Testament Theology: Divine Call and Human Response. Waco: Baylor University Press, 2013.

Landy, Frances. "Vision and Voice in Isaiah." Journal for the Study of the Old Testament 88 (2000): 19-36.

"The Impersonal Voice in the First-person Narrative Fiction." Narrative 12 (2004): 113-151.

Leung Lai, Barbara M. "Voice and Ideology in Ecclesiastes: Reading 'Cross the Grains." Pages 265-278 in Interested Readers: Essays on the Hebrew Bible in Honor of David J. A. Clines. Edited by James K. Aitken, Jeremy M.C. Clines and Christl M. Maier. Atlanta: Society of Biblical Literature, 2013. 
“The Preacher and One's Own 'Text-of-Life'." Pages 214-216 in Global Perspectives on the Old Testament. Edited by Mark Roncace and Joseph Weaver. Upper Saddle River: Pearson, 2013.

“Toward a Version of 'Narratival Hermeneutics'-Reading Ecclesiastes Ethnoculturally with a Chinese Lens: Selfhood, Diaspora Experience, and the Search for Meaning." Pages 36-51 in Reading In-between: How Minoritized Cultural Communities Interpret the Bible in Canada. Edited by Néstor Medina, Alison Hari-Singh and Hyeran Kim-Cragg. Eugene: Pickwick Publications, 2019.

- "Engaging Ecclesiastes Narrativally and Polyphonically with a Chinese Lens: Traditional Wisdom and 'Collective Lived Experience under the Sun' in Dialogue." Pages 306-316 in T \& T Clark Handbook of Asian American Biblical Hermeneutics. Edited by Uriah Y. Kim and Seung Ai Yang. London: T \& T Clark, 2019.

Through the "I" Window: The Inner Life of Characters in the Hebrew Bible. Hebrew Bible Monographs 34. Sheffield: Sheffield Phoenix Press, 2011.

Murphy, Roland. Ecclesiastes. Word Bible Commentary 23A. Dallas: Word, 1992.

"Murphy's Axiom: Every Gnomic Saying Needs a Balancing Corrective." Pages 344-354 in Urgent Advice and Probing Questions. Edited by James L. Crenshaw. Macon: Mercer University Press, 1995.

Newsom, Carol A. "Bakhtin, the Bible, and Dialogic Truth." Journal of Religion 76 (1996): 290-306.

. "Reflection on Ideological Criticism and Postcritical Perspectives." Pages 553557 in Method Matters: Essays on the Interpretation of the Hebrew Bible in Honor of David Patterson. Edited by Joel M. LeMon and Kent Harold Richards. Atlanta: Society of Biblical Literature, 2009.

Perdue, Leo G. Wisdom and Creation: The Theology of Wisdom Literature. Nashville: Abingdon, 1994.

Snodgrass, Klyne. "Reading to Hear: A Hermeneutics of Hearing." Horizons in Biblical Theology 24 (2002): 1-32.

Sternberg, Meir. "The World from the Addressee's Viewpoint: Reception as Representation, Dialogue as Monologue.” Style 20 (1986): 295-318.

Walton, Timothy. "Reading Qoheleth as Text, Author, and Readers." Pages 113-131 in Tradition and Innovation in Biblical Interpretation: Studies Presented to Professor Eep Talstra on the Occasion of His Sixty-fifth Birthday. Edited by W.Th. Van Peursen and J.W. Dyk. Leiden: Brill, 2011.

Professor Barbara M. Leung Lai, Research Professor of Old Testament, Tyndale University, Toronto, Canada, E-mail: blai@tyndale.ca, ORCID: http://orcid.org/00000003-0746-5049. 